\title{
The Application of Audio Visual Media Based on Minangkabau Folklore to Develop Children's Speaking Ability in Kindergarten Kartika 1-7 Padang
}

\author{
Mahyurianti ${ }^{1}$ and Nenny Mahyuddin ${ }^{2}$
}

\author{
${ }^{1}$ Early Childhood Education Department, Padang State University, Padang, Indonesia, mahyurianti.eri@gmail.com \\ ${ }^{2}$ Early Childhood Education Department, Padang State University, Padang, Indonesia, \\ nenny.mahyuddinpaud@gmail.com
}

\begin{abstract}
One effective way of learing and teaching process is to maximize the use of media. Learning media in the form of visuals in the form of pictures, photos, audio in the form of sound recordings, certain sounds, as well as in the combined form of both such as video recordings that contain audio and video elements have changed the paradigm of learning outcomes. One of them is by applying audio-visual media based on Minangkabau folklore to develop children's speaking skills at TK Kartika 1-7 Padang. This is done because applying audiovisual media is one alternative that can be used to maximize children's understanding/children's ability in mastering the material provided by the teacher. It also makes children motivated to continue to learn and hone themselves. referring to these problems, the writing method used is a descriptive method that aims to describe the application of audio-visual media based on Minangkabau folklore to develop children's speaking skills at TK Kartika 1-7 Padang. The population in this study was children in TK Kartika 1-7 Padang who were registered in 2018/2019. The number of children enrolled in the school year is 44, spread in two classes. Based on the development of the children studied, it was concluded that the development of children is still classified as low, from 22 children, 7 of them are in the unfavorable range, including the undeveloped category. invited to speak. Then 8 people are in a fairly good range which is in the category of developing, meaning that the child only speaks two to three words and the child is still guided by the teacher. And 6 other people are in a good range meaning the child is able to speak. 1 child is in a very good range of values because the child is able to speak well and smoothly and the articulation is clear. So that the data shows that children's speaking ability in Kindergarten Kartika 1-7 Padang children need to be improved.
\end{abstract}

Keywords: audiovisual media, minangkabau folklore, peaking abilty

\section{INTRODUCTION}

Education cannot be separated from technological development. Various educational tools and modern educational facilities that support the learning process optimization both at the level of preschool, school, university and also in everyday life (Mahmudah \& Ardi, 2020; Nicolaou, Matsiola, \& Kalliris, 2019; Nuari \& Ardi, 2014). One of them is the presence of media in the learning process. Ratna Saraswati, AAIN Marhaen, (2014: 4) revealed that learning media are tools or stimulus that is used to convey learning messages. He also said that forms of stimulus can be used as a medium such as human relationships or interactions, realia, moving or not images, written text and sound. These five forms of stimulus will help students in terms of learning.

One of the media used in learning and is believed to be more fun is audio visual media. According to Condrosari, (2017: 3-4) audio visual media is a combination of audio and visual media so that the media can be heard and can be seen at the same time. Examples of audio-visual media are television, video or sound slides. Learning media in the form of visuals in the form of pictures, photos, audio in the form of sound recordings, certain sounds, as well as in the combined form of both such as video recordings that contain audio and video elements have changed the paradigm of learning outcomes.

The use of audio visual media is now starting to develop. This can be seen from the number of studies and research journals that discuss audio visual media. According to Eliza, (2017: 153) Minangkabau traditional stories as local wisdom can develop children's character. Local wisdom is a basic capital that can be utilized through learning, especially character learning. Children's stories are one form of copyright that is widely published as material for children. Fairy tales in addition to providing entertainment that is also fun as a medium for conveying educational messages. The story also has the 
purpose of entertaining and providing information to the reader. So the story is an essay that tells the story of something actually happening or a fantasy aimed at entertaining and providing information to the audience in the form of prose.

Ade Kusmiadi, Sriwahyuningsih, (2008: 198) states that although fairy tales are often said to be fictional stories or stories, this does not mean that they are not useful. In the process of its development, fairy tales always activate the intellectual aspects, sensitivity, refinement, emotion, art, fantasy, and imagination to the listeners. Educators must be keen to sort out and choose types and themes of fairy tales that are suitable for children. So children's stories are stories whose stories tell the events of the world of children and aim to provide entertainment and at the same time convey the message of educators and form can be in the form of prose. Parents in ancient times instill techniques and data character to their children through telling tales before sleeping. This oral tradition is a hereditary habit from generation to generation. The moral messages contained in the story are believed to give an impression that touches the inner world of the child. The inner touch will have a long-term effect. This is what is believed to support the development of moral potential in children or in a spiritual perspective called human nature that loves kindness. The traditional Minangkabau story for kindergarten children is a way to introduce children to culture and the values contained therein. (Eliza, 2017: 157). Submitting Minangkabau folklore is certainly closer to Minangkabau children. The ultimate goal is to make the children to have the ability to tell stories or speak from the audio visual displayed in front of the class. It concerns the development of Early Childhood language. Development of speaking ability can be done, both in the family and school environment. The development of language, especially speaking of early childhood, is important to develop communication and interact with others. Tarigan (2008: 15), speaking is the ability to pronounce articulation sounds or words to express, express and convey thoughts, ideas and feelings. Speaking is not just saying sounds or words. Speaking is a means to communicate ideas that are arranged and developed according to the needs of the listener or listener.

Speaking is a process of communication that brings out thoughts or feelings into meaningful sounds of language. The ability to speak does not grow and develop by itself but is preceded by listening skills. Lina Amelia, (2016: 22) states speaking is a process of delivering information, ideas or ideas from the speaker to the listener. The speaker is the communicator while the listener is the communicant. Information conveyed orally can be received by the listener if the speaker is able to convey properly and correctly. According to Aprinawati, (2017: 76) speaking ability is the initial ability that children must have to be able to communicate well. For this reason, speaking ability is the ability at an early stage to be able to communicate properly and correctly. Safangati, (2015: 3) states the ability to speak is influenced by two aspects, namely linguistic and non-linguistic. Both aspects are explained by Nurbiana Dhieni, et al (in Condrosari, 2017: 3.5), namely the linguistic aspect, including: (1) accuracy of speech, (2) placement of pressure, tone, joint, and duration accordingly, (3) choice of words, and (4) accuracy of the target conversation. For non-linguistic aspects, including: (1) posture, views, body language, and appropriate expression, (2) willingness to respect the speech and ideas of others, (3) loudness and fluency in speaking, and (4) relevance, reasoning and mastery of certain topics. Rosmala Dewi (2005: 17) further stressed that the language development of children aged 4 to 6 years includes: (1) mimicking 2 to 4 sequences of numbers, word order, (2) following 2 to 3 commands at once, (3) speak fluently, (4) retell the story that has been told by the teacher, (5) provide information about a thing, (6) mention the names of objects, animals, and (7) tell the pictures that have been provided.

\section{METHODS}

This is quantitative research. The research method used is a descriptive method that aims to describe the application of audio-visual media based on the Minangkabau folklore to develop children's speaking skills at TK Kartika 1-7 Padang. The purpose of writing using this descriptive method is to describe or describe something systematically, factually, and accurately about the facts and properties of the phenomena to be investigated.

The population in this study was children in TK Kartika 1-7 Padang who were registered in 2018/2019. The number of children enrolled in the school year is 44 , spread in two classes. This writing uses three variables, namely, the application of audio visual media as a dependent variable based on the Minangkabau folklore, the dependent variable is to develop children's speaking ability as a free variable and the subject of this research is the children in TK Kartika 1-7 Padang. The acquisition of data in this study is the result of the application of audiovisual media based on Minangkabau folklore to develop children's speaking skills at Tk Kartika 1-7 Padang by paying attention to linguistic and non-linguistic aspects. Data is collected and processed based on data collection techniques and data analysis techniques. The instrument used in this writing is a test of children's speaking ability which is assessed directly by the author by using the rubric of the assessment of children's speaking abilities at Tk Kartika 1-7 Padang. The instrument used in this writing is a test of children's speaking ability which is assessed directly by the author by using the rubric of the assessment of children's speaking ability at Tk Kartika 1-7 Padang based on aspects assessed in the form of tables, namely aspects of language and non-language.

\section{RESULT AND DISCUSSION}

Based on observations made on 10-20 November 2018 at TK Kartika 1-7 Padang, the following problems were raised: (1) children feel bored and bored in learning because teachers only use media that is not varied (2) children tend to enjoy learning and comfortable learning by using audio visual because children are accustomed to watching television. This can be seen when children watch television or play with games on their mobile phones or tablets (3) if viewed from the spirit of children, children are more excited when presented with media that can be heard and can be seen directly (such as tablets, mobile 
phones), (4) The number of teachers in kindergarten who are technologically illiterate, which become the main obstacle, do not provide a variety of media, especially audio-visual media.

Furthermore, based on the development of the children studied, it was concluded that the development of children is still classified as low, from 22 children, 7 of them are in the unfavorable range, including the undeveloped category invited to speak. Then 8 people are in a fairly good range which is in the category of developing, meaning that the child only speaks two to three words and the child is still guided by the teacher. And 6 other people are in a good range meaning the child is able to speak. 1 child is in a very good range of values because the child is able to speak well and smoothly and the articulation is clear. So that the data shows that children's speaking ability in Kindergarten Kartika 1-7 Padang children need to be improved. The author took the place of research at TK Kartika 1-7 Padang due to the writer as a teaching / educator at the ground. In addition, information disclosure in providing valid and accountable data. Furthermore, access to TK Kartika 1-7 Padang is very easy because it is located in the city center.

\section{CONCLUSION}

Children feel bored in learning because teachers only use media that are not varied (2) children tend to prefer learning and comfortable learning by using audio visual because children are accustomed to watching television. This can be seen when children watch television or play with games on their mobile phones or tablets (3) if viewed from the spirit of children, children are more excited when presented with media that can be heard and can be seen directly (such as tablets, mobile phones), (4) The number of teachers in kindergarten who are technologically illiterate, which become the main obstacle, do not provide a variety of media, especially audio-visual media. One of them is by applying audiovisual media based on Minangkabau folklore to develop children's speaking skills at TK Kartika 1-7 Padang. This is done because applying audio-visual media is one alternative that can be used to maximize children's understanding / children's ability in mastering the material provided by the teacher. It also makes children motivated in their desire to continue to learn and hone themselves. Based on that, according to Sadiman (2010: 2) the benefits of media in learning for children like children are as follows. (1) Learning will attract more attention of children so that it can foster motivation to learn. (2) Teaching and learning materials will be more clearly meaningful so that they can be better understood by children, and allow children to better master teaching objectives. (3) The method of teaching will be more varied, not merely verbal communication through spoken words by the teacher, so that the child does not get bored and the teacher does not run out of energy, especially if the teacher teaches for every class hour. (4) Children do more learning activities, because not only listen to the teacher's description, but also other activities such as observing, doing, demonstrating (talking) and others. Based on some of the explanations and research above regarding the development of learning media specifically in kindergarten researchers important to conduct research on "The Application of Audio Visual Media Based on Minangkabau Folklore to Develop Children's Speaking Ability in Kindergarten Kartika 1-7 Padang.

\section{REFERENCES}

[1] Ade Kusmiadi, Sriwahyuningsih, dan Y. N. (2008). Strategi Pembelajaran Paud Melalui Metode Dongeng Bagi Pendidik Paud. Jurnal Ilmiah VISI PTK-PNF - Vol. 3, No.2 - 2008, 3(2), 198-203.

[2] Aprinawati, L. (2017). Penggunaan Media Gambar Seri Untuk Meningkatkan Kemampuan Berbicara Anak Usia Dini. Jurnal Obsesi Journal of Early Childhood Education, 1(1. ISSN 2549-8959), 7280.

[3] Condrosari, G. Y. (2017). Meningkatkan Kemampuan Membaca Permulaan Melalui Media Audio Visual Anak Usia 5-6 Tahun Di Tk Pkk Bener Kecamatan Tegalrejo (Improve The Ability To Read The Beginning Through The Audio Visual Media Of Children Aged 5-6 Years In Tk Pkk Bener Kecamatan Tega. Jurnal Pendidikan Anak Usia Dini Edisi 4 Tahun Ke-6 2017 Aspek. Pgpaud/Paud FIP UNY, 4(6), 377-389.

[4] Eliza, D. (2017). Pengembangan Model Pembelajaran Karakter Berbasis Cerita Tradisional Minangkabau Untuk Anak Usia Dini. Pedagogi: Jurnal Anak Usia Dini Dan Pendidikan Anak Usia Dini. P-ISSN: 2599-0438; E-ISSN: 2599-042X., 3(3b), 153-163.

[5] Mahmudah, R., \& Ardi, H. (2020). The use of instagram platform toward junior high school students' speaking ability. Advances in Social Science, Education and Humanities Research, 411(Icoelt 2019), 364-369. https://doi.org/10.2991/assehr.k.200306.061

[6] Nicolaou, C., Matsiola, M., \& Kalliris, G. (2019). Technology-enhanced learning and teaching methodologies through audiovisual media. Education Sciences, 9(3), 1-13. https://doi.org/10.3390/educsci9030196

[7] Nuari, F., \& Ardi, H. (2014). Using Camtasia Studio 8 to produce learning video to teach English through e-learning. Journal of English Language Teaching, $3(1), 259-267$.

[8] Ratna Saraswati, A.A.I.N Marhaen, N. K. S. (2014). Implementasi Multimedia Bermuatan Pendidikan Karakter Untuk Meningkatkan Kecerdasan Emosi Dan Keterampilan Berpikir Kreatif. Program Studi Pendidikan Dasar, Program Pascasarjana e-Journal Program Pascasarjana Universitas Pendidikan Ganesha. Program Pascasarjana Universitas Pendidikan Ganesha, 4(1), 1-12. Retrieved from http://119.252.161.254/ejournal/index.php/jurnal_pendas/article/view/1071

[9] Tarigan, Hendry Guntur. (2008). Berbicara sebagai Suatu Keterampilan Berbahasa. Bandung: Angkasa. 